\title{
Erratum: "Experimental Study of a Multi-Tube ICS Solar Water Heating System in Mild Climates" [Applied Solar Energy (1), 46 (2010)]
}

F. Fooladi and H. Taheriani

Babol University of Technology, Mechanical Engineering Department, Shariati Av., Babol 47144, India Received October 23, 2009

DOI: $10.3103 / \mathrm{S} 0003701 \mathrm{X} 10030175$

The correct name of the second author is H. Taherian. The correct country of affiliation is Iran. 